\title{
Modulation of $\gamma$-Secretase Activity by a Carborane-Based Flurbiprofen Analogue
}

\author{
Stefan Saretz ${ }^{1,2}$, Gabriele Basset ${ }^{3}$, Liridona Useini ${ }^{1}$, Markus Laube ${ }^{4}{ }^{(}$, Jens Pietzsch ${ }^{4,5}\left(\mathbb{D}\right.$, Dijana Drača ${ }^{6}(\mathbb{D}$, \\ Danijela Maksimović-Ivanić ${ }^{6}{ }^{(}$, Johannes Trambauer ${ }^{3}$, Harald Steiner ${ }^{3,7}$ and Evamarie Hey-Hawkins ${ }^{1, *(1)}$
}

Citation: Saretz, S.; Basset, G.; Useini, L.; Laube, M.; Pietzsch, J.; Drača, D.; Maksimović-Ivanić, D.; Trambauer, J.; Steiner, H.; Hey-Hawkins, E. Modulation of $\gamma$-Secretase Activity by a Carborane-Based Flurbiprofen Analogue. Molecules 2021, 26, 2843. https://doi.org/10.3390/ molecules 26102843

Academic Editors: Yinghuai Zhu, Narayan S. Hosmane and Igor B. Sivaev

Received: 15 March 2021

Accepted: 6 May 2021

Published: 11 May 2021

Publisher's Note: MDPI stays neutral with regard to jurisdictional claims in published maps and institutional affiliations.

Copyright: (c) 2021 by the authors. Licensee MDPI, Basel, Switzerland. This article is an open access article distributed under the terms and conditions of the Creative Commons Attribution (CC BY) license (https:/ / creativecommons.org/licenses/by/ $4.0 /)$.
1 Institut für Anorganische Chemie, Universität Leipzig, Johannisallee 29, D-04103 Leipzig, Germany; ssaretz@mannin.de (S.S.); dona_u001@hotmail.com (L.U.)

2 Chemische Biologie, Helmholtz-Zentrum für Infektionsforschung, Inhoffenstraße 7, D-38124 Braunschweig, Germany

3 Biomedical Center Munich (BMC), Metabolic Biochemistry, Ludwig-Maximilians-University, Feodor-Lynen-Straße 17, D-81377 München, Germany; gabriele.basset@mail03.med.uni-muenchen.de (G.B.) johannes.trambauer@mail03.med.uni-muenchen.de (J.T.); harald.steiner@mail03.med.uni-muenchen.de (H.S.)

4 Department of Radiopharmaceutical and Chemical Biology, Institute of Radiopharmaceutical Cancer Research, Helmholtz-Zentrum Dresden-Rossendorf (HZDR), Bautzner Landstraße 400, D-01328 Dresden, Germany; m.laube@hzdr.de (M.L.); j.pietzsch@hzdr.de (J.P.)

5 Faculty of Chemistry and Food Chemistry, School of Science, Technische Universität Dresden, 01069 Dresden, Germany

6 Department of Immunology, Institute for Biological Research "Siniša Stanković", National Institute of Republic of Serbia, University of Belgrade, Bul. Despota Stefana 142, 11060 Belgrade, Serbia; dracadiana@gmail.com (D.D.); nelamax@ibiss.bg.ac.rs (D.M.-I.)

7 German Center for Neurogenerative Diseases (DZNE) Munich, Feodor-Lynen-Straße 17, D-81377 München, Germany

* Correspondence: hey@uni-leipzig.de; Fax: +49-341-9731136151

Abstract: All over the world, societies are facing rapidly aging populations combined with a growing number of patients suffering from Alzheimer's disease (AD). One focus in pharmaceutical research to address this issue is on the reduction of the longer amyloid- $\beta(A \beta)$ fragments in the brain by modulation of $\gamma$-secretase, a membrane-bound protease. $R$-Flurbiprofen (tarenflurbil) was studied in this regard but failed to show significant improvement in AD patients in a phase 3 clinical trial. This was mainly attributed to its low ability to cross the blood-brain barrier (BBB). Here, we present the synthesis and in vitro evaluation of a racemic meta-carborane analogue of flurbiprofen. By introducing the carborane moiety, the hydrophobicity could be shifted into a more favourable range for the penetration of the blood-brain barrier, evident by a $\log \mathrm{D}_{7.4}$ value of 2.0. Furthermore, our analogue retained $\gamma$-secretase modulator activity in comparison to racemic flurbiprofen in a cellbased assay. These findings demonstrate the potential of carboranes as phenyl mimetics also in AD research.

Keywords: Alzheimer; carborane; flurbiprofen; $\gamma$-secretase modulator (GSM); small molecule; amyloid- $\beta(\mathrm{A} \beta)$ peptide; phenyl mimetic

\section{Introduction}

Alzheimer's disease (AD) is a neurodegenerative disease, which is characterised by slow but progressive cognitive decline [1]. To this day it is incurable, and current treatments apply acetyl cholinesterase inhibitors or $N$-methyl-D-aspartate receptor antagonists, thereby offering only short-term symptomatic relief [1,2]. At the cellular level, the pathology of AD is characterised by neuritic extracellular plaques and intracellular neurofibrillary tangles [1] The plaques consist mainly of amyloid- $\beta$ (A $\beta$ ) peptide fibrils. $A \beta$ peptides are produced in different lengths with $A \beta 38, A \beta 40$, and $A \beta 42$ being the most abundant species [3]. The longer and more aggregation-prone $A \beta 42$ (and $A \beta 43$ ) [3] species facilitates $A \beta$ aggregation and is the main component of parenchymal plaques; therefore, increased $A \beta 42: A \beta 40$ 
ratios are believed to be a major trigger of the disease [4]. The different $A \beta$ species are generated by sequential cleavages of the amyloid precursor protein (APP). APP is first processed by $\beta$-secretase resulting in a 99 amino acid long C-terminal fragment, which is then further processed within its transmembrane domain by $\gamma$-secretase [3]. In this step, $\gamma$-secretase produces the different $A \beta$ species by sequential carboxy-terminal trimming of the $A \beta 48$ and $A \beta 49$ species that are initially generated by the first intramembrane cleavage by $\gamma$-secretase [3]. This stepwise cleavage activity, also called $\gamma$-secretase processivity, is impaired by most inherited AD-causing mutations, resulting in an increased production of more pathogenic, longer $A \beta 42$ and A $\beta 43$ species [3]. Besides its role in APP cleavage, $\gamma$-secretase is also important for many other physiological processes such as the Notch signalling pathway, the most prominent example [5].

In order to reduce $A \beta$ plaques in patients, potent $\gamma$-secretase inhibitors (GSIs), such as semagacestat, were developed. Unfortunately, semagacestat caused severe side effects, including weight loss, skin cancer and infections, in a phase 3 clinical trial that led to the discontinuation of most GSI study programs [6-8]. The side effects are considered to be the result of a mechanism-based toxicity due to the interference with the cleavage of other crucial $\gamma$-secretase substrates such as the transmembrane receptor Notch, which is important for nuclear signalling [6].

An alternative to the inhibition of $\gamma$-secretase is to modulate its cleavage activity. This concept is based on the findings of Weggen et al. (2001) that certain non-steroidal anti-inflammatory drugs (NSAIDs) lead to a reduced production of $A \beta 42$, thereby lowering the $A \beta 42: A \beta 40$ ratio in mouse brain and cell culture [9]. This change in the production ratios was termed $\gamma$-secretase modulation, and substances having this profile were called $\gamma$-secretase modulators (GSMs) [10,11]. In a follow-up study, Eriksen et al. could show that flurbiprofen displayed the highest potency to lower the $\mathrm{A} \beta 42: \mathrm{A} \beta 40$ ratio in $\mathrm{H} 4$ cells and mice [12]. No difference in GSM potency was observed for $S-, R$ - or racemic flurbiprofen [12]. In order to avoid side effects due to the fact of COX inhibition, only $R$-flurbiprofen (tarenflurbil) was tested in a clinical phase 2 trial. Patients with mild AD showed a significantly slower cognitive decline in comparison to the placebo group. In patients with moderate AD, however, no significant difference was observed [13]. Unfortunately, the previously observed significant effect could not be reproduced in the follow-up phase 3 clinical trial [14]. The failure of $R$-flurbiprofen in phase 3 was attributed to the drug's poor penetration of the blood-brain barrier (BBB) [15]. Therefore, future developments tried to improve this particular feature of the drugs, e.g., by increasing the compound's hydrophobicity ( $\log \mathrm{D}$ of 1 to 3 , respectively $\log \mathrm{D} \geq 1.5)$ [16,17]. Both $\log \mathrm{D}$ ranges are considered to be beneficial for BBB crossing.

Although it became clear over the past years that the underlying pathomechanism of $\mathrm{AD}$ is not sufficiently understood and other factors besides $\mathrm{A} \beta$ are increasingly discussed with respect to the development and treatment of the disease, GSMs are still a valid option as part of a combination therapy [2]. Since the failure of $R$-flurbiprofen, constant effort has been made to develop new and more potent GSMs. Most of these next-generation GSMs share an imidazole-aryl moiety, first introduced by the company Eisai [11]. Unfortunately, most of them do not yet combine good in vitro and in vivo properties, resulting in poor solubility in water and potential hepatotoxicity [11]. Therefore, NSAIDs like flurbiprofen and their central structural motif (2-arylpropionic acid) should not yet be fully abandoned for the development of anti-AD drugs.

Among others, Peretto et al. have tried to improve the drug-like properties of this structure. They addressed the metabolically unstable $3^{\prime}$ - and $4^{\prime}$-positions at the terminal ring of flurbiprofen, which normally is hydroxylated or methoxylated [18-20]. They could show that bulky moieties at these positions, such as $4^{\prime}$-trifluoromethyl, $3^{\prime}, 4^{\prime}$-dichloro or $4^{\prime}$ (4-trifluoromethylcyclohexyloxy) substituents, are favourable for a reduction of $\mathrm{A} \beta 42$ production in H4 cells that express APP harbouring the "Swedish" familial AD mutation [20]. Further substitution of the carboxylic acid with known carboxylic acid bio-isosteres, such as tetrazole, in order to minimise plasma protein binding, however, was not beneficial for 
the compound's ability to reduce $A \beta 42$. It also resulted in additional interactions of the compound with cytochrome P450 (CYP) isoforms other than CYP2C9 [20]. Furthermore, results from Abdul-Hay et al. suggest that the carboxylic acid group is crucial for flurbiprofen's GSM activity [21]. Notably, the 4-butylnitrat ester of flurbiprofen, HCT-1026, showed a complete inverse GSM activity profile marked by increasing the $A \beta 42$ levels due to the inhibition of $\mathrm{A} \beta 42$ clearance [21,22].

Carboranes $\left(\mathrm{C}_{2} \mathrm{~B}_{10} \mathrm{H}_{12}\right.$, dicarba-closo-dodecaborane(12)s) are frequently used as phenyl mimetics for biologically active compounds [23]. Carboranes are highly hydrophobic, nontoxic and metabolically stable boron clusters in which two $\mathrm{BH}^{-}$vertices are replaced by neutral $\mathrm{CH}$ groups. The carbon atoms can be selectively deprotonated by strong bases and functionalised easily. The three different isomers of carboranes, ortho-(1,2-dicarba-closododecaborane(12)), meta-(1,7-dicarba-closo-dodecaborane(12)) and para-carborane (1,12dicarba-closo-dodecaborane(12)), show increased chemical and biological stability in this order. Thus, ortho-carborane can be thermodynamically converted to meta- and paracarborane at high temperatures [24,25]. Due to the fact of their remarkable stability and hydrophobicity, a growing interest in carboranes for medicinal chemistry applications is becoming evident [26-34]. Although the first use of carborane derivatives in boron neutron capture therapy (BNCT) dates back to the 1950s [35], it was only in 2009 that Hawkins et al. showed conclusively that a carborane derivative, namely, a neutral rhenacarborane, can cross the BBB [36]. In 2011, Crossley et al. then showed that both the neutral ortho-carborane and the corresponding anionic nido-carborane derivative of pyrazolopyrimindines were taken up effectively into T98G human glioma cells [37]. The first carborane-based compound able to affect the central nervous system (CNS) was published in 2014 by Wilkinson et al. [34]. Here, the antidepressant activity of a highly hydrophobic neutral closo-carborane derivative $\left(\log \mathrm{D}_{7.4}=4.29\right)$ was compared with its more hydrophilic monoanionic nidocarborane counterpart $\left(\log \mathrm{D}_{7.4}=1.44\right)$ [34]. In the forced swim test (FST) performed with mice, only the nido-compound showed antidepressant activity, proving its ability to cross the $\mathrm{BBB}$ in vivo [34]. It was rationalised by Wilkinson et al. that the more favourable $\log \mathrm{D}_{7.4}$ value of the nido-compound $\left(\log \mathrm{D}_{7.4}<3\right)$ was responsible for crossing the $\mathrm{BBB}$, since the trend of activity between the ortho- and nido-compounds was reversed when performing in vitro $\mathrm{IC}_{50}$ measurements on the targeted $\mathrm{P}_{2} \mathrm{X}_{7}$ receptor [34].

In this work, we present our approach to replace the terminal phenyl ring of the flurbiprofen scaffold with a bulkier and biologically stable meta-carborane moiety to increase the hydrophobicity into a $\log \mathrm{D}_{7.4}$ range from 1 to 3 for potentially better BBB penetration capabilities while retaining its ability to reduce $A \beta 42[23,26]$.

\section{Results}

\subsection{Synthesis}

The meta-carborane analogue of flurbiprofen (5) was prepared in four steps (Scheme 1). Starting from the 9-iodo-meta-carborane (1), an ethylphenyl moiety was introduced via Kumada coupling employing freshly prepared 4-ethylphenylmagnesium bromide. After purification, 2 was obtained in good yield. In the next step, an allylic bromination with $N$-bromosuccinimide (NBS) was carried out without any additional radical starter, as such highly reactive compounds lead to complete decomposition of the starting material. The resulting benzylic bromide 3 was used without further purification. The following substitution of the bromide was carried out with excess of tin tetrachloride $\left(\mathrm{SnCl}_{4}\right)$ and not as reported by Reetz et al. in high catalytic amounts [38]. In the final step, the nitrile was hydrolysed in a mixture of glacial acetic acid and concentrated hydrochloric acid leading to the desired product 5 in 36\% yield and the partially hydrolysed amide 6 in 38\% yield, both as racemic mixtures. Both could be separated by means of normal phase column chromatography. Acidic conditions instead of the more common basic conditions were chosen as a general synthetic strategy suitable not only for meta-carborane but also for the more base-labile ortho-carborane derivatives, if required. 


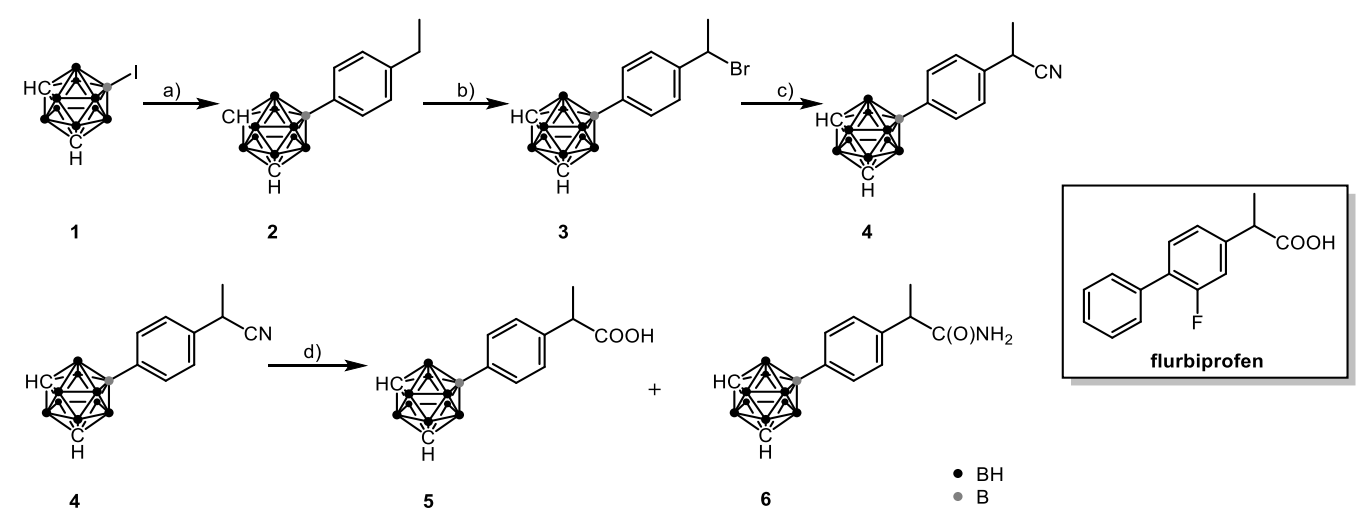

Scheme 1. Synthesis of compound 5. (a) 4-Ethylphenylmagnesium bromide, $\mathrm{CuI},\left[\mathrm{PdCl}_{2}\left(\mathrm{PPh}_{3}\right)_{2}\right], \mathrm{Et}{ }_{2} \mathrm{O}, 85 \%$; (b) NBS, hv, $\mathrm{CCl}_{4}$; (c) $\mathrm{SiMe}_{3} \mathrm{CN}, \mathrm{SnCl}_{4}, \mathrm{CH}_{2} \mathrm{Cl}_{2}, 99 \%$ (over two steps); (d) $\mathrm{HCl}_{\text {conc. aq, }} \mathrm{AcOH}_{\text {conc. }}, 36 \%$ for 5 and $38 \%$ of the partially hydrolysed amide 6 (separable by chromatography); all yields were isolated yields.

\subsection{Determination of COX Inhibition}

Since compound $\mathbf{5}$ is derived from one of the most common unselective cyclooxygenase (COX) inhibitors, its ability to inhibit both isoforms, ovine COX-1 and human COX-2, was determined. nido-Indoborin (compound 2 in [39]), a carborane-based derivative of indomethacin, was also tested in the same assay to exclude interference of the carborane moiety (Table 1). No inhibitory activity of 5 was observed in the performed enzyme-based assay (Table 1), indicating that the modification abolished the COX inhibitory activity of the parent compound. Of note was the measured $\mathrm{IC}_{50}(\mathrm{COX}-2)$ value for nido-indoborin that was approximately 18 times higher than the published one determined by an $\left[{ }^{14} \mathrm{C}\right]$ arachidonic acid-based assay using ovine COX-1 and murine COX-2 [39]. This difference might be explained by differences in the assay setup, which notably differs in the applied final arachidonic acid concentration. In both assays, the inhibitors compete with arachidonic acid for binding in the cyclooxygenase active site so that the $\mathrm{IC}_{50}$ value is dependent on the affinity of the inhibitor $\left(K_{\mathrm{i}}\right)$, the concentration of the substrate $([\mathrm{S}])$ and the Michaelis constant $\left(\mathrm{K}_{\mathrm{M}}\right)$ of the substrate to the enzyme according to the Cheng-Prusoff equation $\left(K_{\mathrm{i}}=\mathrm{IC}_{50} /\left(1+\left([\mathrm{S}] / \mathrm{K}_{\mathrm{M}}\right)\right)\right.$ [40]. In the $\left[{ }^{14} \mathrm{C}\right]$ arachidonic acid-based assay [39] that was originally established by Kalgutkar et al., typically a final concentration of $2 \mu \mathrm{M}$ $\left[{ }^{14} \mathrm{C}\right]$ arachidonic acid is applied [41]. Using a representative $\mathrm{K}_{\mathrm{M}}$ of $6.5 \mu \mathrm{M}$ of arachidonic acid to His-tagged COX-2, the calculated affinity of the inhibitor to the enzyme would be $K_{\mathrm{i}(\mathrm{COX}-2 \text {, calculated })}=39 \mathrm{nM}$ [42]. In this work, $100 \mu \mathrm{M}$ arachidonic acid was applied according to the manufacturer's instructions for the "COX Fluorescent Inhibitor Screening

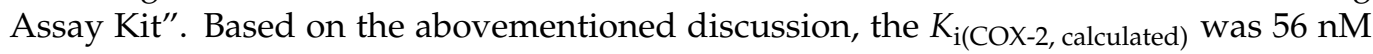
and, hence, comparable to the previously determined binding potency of nido-indoborin to COX-2. This highlights the importance to use a well-established standard compound within the assay. In this and previous work, we used celecoxib as the internal standard and experimentally determined an $\mathrm{IC}_{50}$ (COX-2) value of $38 \pm 20 \mathrm{nM}$ ( $n=6$ biological replicates) converting to a $K_{\mathrm{i}(\mathrm{COX}-2 \text {, calculated })}=2.3 \pm 1.2 \mathrm{nM}$. This value is in good accordance with the experimentally determined affinity of $\left[{ }^{3} \mathrm{H}\right]$ celecoxib to COX-2 of $\mathrm{K}_{\mathrm{D}}=2.3 \mathrm{nM}$ determined by Hood et al. [43].

Table 1. $\mathrm{IC}_{50}$ values of compound 5 and nido-indoborin for the inhibition of COX-1 and COX-2. Tested with the commercial "COX Fluorescent Inhibitor Screening Assay Kit" from Cayman Chemical Company.

\begin{tabular}{ccccc}
\hline Enzyme & Compound 5 & \multicolumn{2}{c}{ nido-Indoborin } & Celecoxib \\
& & Measured & Reported [39] & \\
\hline COX-1 & $>100 \mu \mathrm{M}$ & $>100 \mu \mathrm{M}$ & $>4 \mu \mathrm{M}$ & $100 \mu \mathrm{M}$ \\
COX-2 & $>100 \mu \mathrm{M}$ & $0.91 \mu \mathrm{M}$ & $0.051 \mu \mathrm{M}$ & $0.04 \pm 0.02 \mu \mathrm{M}$ \\
\hline
\end{tabular}




\subsection{Determination of $\log D_{7.4}$}

The $\log \mathrm{D}_{7.4}$ value for compound 5 and nido-indoborin was determined by a previously reported HPLC method [44], which was originally described by Donovan and Pescatore [45]. Under standard conditions (method 2, Table 2) the $\log \mathrm{D}_{7.4}$ of compound 5 was found to be 1.86 and, hence, higher in comparison to flurbiprofen [46]. For nidoindoborin, the $\log \mathrm{D}_{7.4}$ was determined to be 2.05 . Of note, applying another column (i.e., Chromolith Speed ROD RP-18E 50 (method 1, Table 2)) instead of the typically used Asahipak ODP-50 4B, in an equal setting resulted in comparable $\log \mathrm{D}_{7.4}$ values. The measured variances in $\log \mathrm{D}_{7.4}$ measurements between the two compounds and the two methods lie in the typical range of the method, and both compounds can be seen as equally hydrophobic [45]. This confirms that the replacement of a phenyl ring with a carborane moiety indeed increased the hydrophobicity and could therefore result in an increased BBB penetration of compound $\mathbf{5}$ compared to flurbiprofen.

Table 2. $\log \mathrm{D}_{7.4}$ of compound 5 and nido-indoborin. Method 1: Chromolith Speed ROD RP-18E 50 from Merck, method 2: Asahipak ODP-50 4B $4.6 \times 50$ from Shodex.

\begin{tabular}{cccc}
\hline Method & Compound 5 & nido-Indoborin & $\begin{array}{c}\text { Flurbiprofen [46] } \\
\text { (Shake Flask) }\end{array}$ \\
\hline 1 & 2.00 & 1.94 & 0.91 \\
\hline
\end{tabular}

\subsection{Determination of Cytotoxicity}

The toxicity of compound 5 up to a concentration of $100 \mu \mathrm{M}$ for $48 \mathrm{~h}$ incubation time was determined in several cell lines by employing the 3-(4,5-dimethylthiazol-2-yl)-2,5diphenyltetrazolium bromide (MTT) and crystal violet (CV) tests and presented as $\mathrm{IC}_{50}$ values (Table 3). The used human tumour (i.e., melanoma A375, colon cancer HCT116 and HT29, and glioblastoma LN229 and U251) and rodent tumour (i.e., mouse melanoma B16 and B16-F10; rat glioma C6) cell lines as well as murine transformed non-malignant fibroblast cell line $\mathrm{NIH} / 3 \mathrm{~T} 3$ differed in their rates of COX-1 and COX-2 expression.

Table 3. Cytotoxicity of compound 5 presented as $\mathrm{IC}_{50}$ values. All values are given in (mean $\pm \mathrm{SD}$ ) $\mu \mathrm{M}$. A375: human melanoma cancer cell line expressing COX-1 and COX-2 [47]. HCT116: human colon cancer cell line expressing COX-1 but not COX-2 [48]. HT29: human colon cancer cell line expressing COX-1 and COX-2 [48]. LN229 and U251: human glioblastoma cell lines non-expressing COX-2 [49,50]. NIH/3T3: mouse fibroblast cell line with expression of COX-1 and low expression of COX-2 [51]. B16 and its metastatic clone, B16-F10, murine melanoma cell lines, expressing both COX-1 and COX-2 [52]. C6: rat glioma cell line expressing both COX-1 and COX-2 [53].

\begin{tabular}{cccccc}
\hline & Human & & \multicolumn{3}{c}{ Rodent } \\
\hline Cell Line & MTT & CV & Cell Line & MTT & CV \\
\hline A375 & $96 \pm 5.9$ & $>100$ & B16 & $79 \pm 2.4$ & $93.7 \pm 3.8$ \\
HCT116 & $>100$ & $>100$ & B16-F10 & $74.7 \pm 0.9$ & $95 \pm 4.6$ \\
HT29 & $>100$ & $>100$ & NIH/3T3 & $90 \pm 10$ & $>100$ \\
LN229 & $95 \pm 7.1$ & $93.3 \pm 9.5$ & C6 & $92.8 \pm 4.8$ & $99.4 \pm 0.8$ \\
U251 & $77.5 \pm 7.2$ & $90.1 \pm 7.1$ & & & \\
\hline
\end{tabular}

According to the obtained data, compound 5 did not disturb the viability of human melanoma A375 and human colon cancer cell lines HT29 and HCT116, human glioma cell line LN229 as well as the rat glioblastoma cell line C6. On the other hand, a slightly toxic effect in the high micromolar range could be detected for the human glioblastoma cell line U251 as well for the murine cell lines B16, B16-F10 and NIH/3T3. Overall, compound 5 was not cytotoxic against the tested cell lines. 


\subsection{Determination of GSM Activity}

The $\gamma$-secretase modulator (GSM) activity of compound 5 was tested on human embryonic kidney (HEK) 293 cells stably overexpressing "Swedish mutant" APP (HEK/sw), a well-established cell culture model to assess GSM activity [54,55]. The effect of compound 5 on $\mathrm{A} \beta$ production was analysed in comparison to flurbiprofen over a relevant and cell tolerable concentration range (Figure 1).

(a)

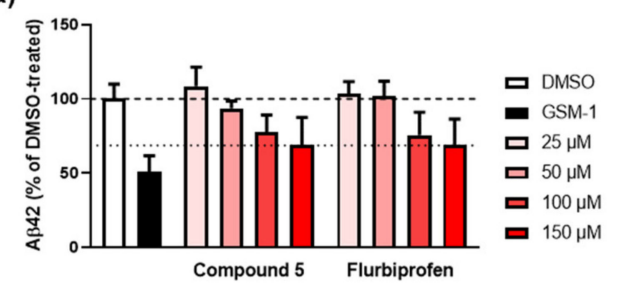

(b)

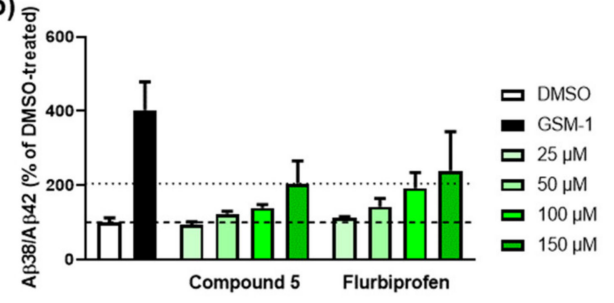

(c)

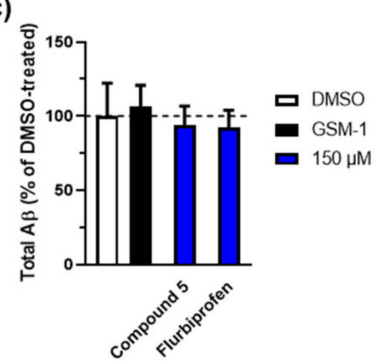

(d)

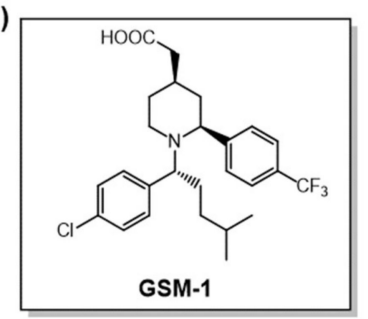

Figure 1. Compound 5 is a GSM with similar potency as flurbiprofen: (a) dose-dependent lowering of $A \beta 42$, (b) dose-dependent increase in $\gamma$-secretase processivity, (c) stable maintenance of total $A \beta$ levels (sum of measured $A \beta 38, A \beta 40$, and $A \beta 42$ ) at the highest effective concentration. Data in (a-c) are represented as the mean $\pm \mathrm{SD}$ ( $n=$ at least 6 biological replicates), the concentration of GSM-1 in all experiments was $1 \mu \mathrm{M}$. A $\beta 42$ data in (a) are represented as ratio of total A $\beta$. (d) Structure of GSM-1 [56].

As shown in Figure 1a, a clear dose-dependent decrease in the pathogenic $A \beta 42$ species was observed, which, as expected, was much weaker than that of $1 \mu \mathrm{M}$ GSM-1 (Figure 1d), a potent acidic GSM used as the positive control [54]. As expected for a flurbiprofen-type GSM, compound 5 increased the ratio of short $A \beta 38$ to the longer $A \beta 42$ demonstrating that it elicited an increased processivity of the stepwise cleavage by $\gamma$ secretase (Figure $1 b$ ). The sum of all measured $A \beta$ species ( $A \beta 38, A \beta 40$ and $A \beta 42)$, as assessed at the most effective concentration of $150 \mu \mathrm{M}$, did not decrease significantly in comparison to the DMSO control, confirming that compound $\mathbf{5}$ is indeed a GSM and not a GSI (Figure 1c). The stable total $A \beta$ levels also indicated that the substance was not harmful to the cells at the concentrations used in these assays. Comparison of these results to those of flurbiprofen suggest that the incorporation of a carborane moiety did neither reduce nor improve the modulatory activity of the compound.

\section{Discussion}

As ortho-carborane derivatives are readily deboronated under basic conditions $[39,57]$, the more stable meta-carborane derivative was employed in our studies. Based on the findings of Wilkinson et al. [34], we wanted to ensure that the flurbiprofen derivative, already carrying one negative charge under physiological conditions, does not undergo deboronation with formation of a nido-carborane species, thus resulting in a dianion. A higher negative charge was expected to result in a decrease in $\log \mathrm{D}_{7.4}$ below the desired range of one to three as well as an increase in electrostatic repulsion with the negatively charged cell membrane, thus making an active or passive transport through the membrane almost impossible. 
In the GSM activity assays, racemic compound 5 was able to reduce the amount of produced extracellular $A \beta 42$, thereby lowering the $A \beta 42: A \beta 40$ ratio. Together with the higher relative amount of $\mathrm{A} \beta 38$, this could lead to a reduction of amyloid plaque formation if taken up into the brain. The effect on $A \beta$ production is comparable to that of flurbiprofen, but could not reach the activity of GSM-1 (Figure 1d), a highly potent second-generation GSM $[54,55]$, indicating that introducing a carborane moiety did not result in improved GSM activity. The steric demand of the carborane moiety of compound 5 might be too high. In line with this, Peretto et al. observed that introduction of two chlorine atoms at positions $3^{\prime}$ and $5^{\prime}$ of flurbiprofen's terminal ring, leading to an overall more globular steric demand, were not as beneficial as introduction at positions $3^{\prime}$ and $4^{\prime}$. An introduction of a chlorine atom at position $2^{\prime}$ blocked the formation of different conformations completely, resulting in a highly sterically demanding compound. This even led to an almost GSM-inactive derivative [20]. In this light, it is noteworthy that even with a sterically demanding carborane (van der Waals volumes: rotating benzene $102 \AA^{3}$; meta-carborane $143 \AA^{3}$ ) [58], it was possible to retain the GSM activity. The same could not be achieved by commonly substituted phenyl rings [20], underlining the value of carboranes as unique phenyl mimetics.

The inability of compound 5 to inhibit COX activity was unexpected. Instead, at least a minor inhibitory activity was suspected, due to the structural similarity to flurbiprofen. Although compound 5 was much more hydrophobic than racemic flurbiprofen $\left(\log \mathrm{D}_{7.4}=0.91\right)$, which might lead to solubility issues [46], the measured strong selectivity of indoborin for COX-2 proves that hydrophobicity should not affect the assay system itself. In addition, no precipitation was observed during the assay, and the carborane's globular structure should sufficiently prevent $\pi-\pi$ stacking. Thus, a simple solubility problem in the COX assay is unlikely but cannot be ruled out completely. However, this lack of COX inhibition could result in a compound that might not cause the cardiovascular and gastrointestinal side effects that are linked to inhibition of COX-1/2 by NSAIDs [59]. In this regard, the lack of activity by compound $\mathbf{5}$ on both COX isoforms is an important advantage over flurbiprofen.

The $\log \mathrm{D}_{7.4}$ value of compound 5 could be successfully shifted to a range of $\log \mathrm{D}_{7.4}=1-3$, $\log \mathrm{D}_{7.4} \geq 1.5$, required for $\mathrm{BBBcrossing}[16,17]$. The value is in a range comparable to drugs like dexamethasone $\left(\log \mathrm{D}_{7.4}=1.97 \pm 0.03\right)$, a known BBB-crossing drug or the CNS-active anionic nido-carborane compound by Wilkinson et al. $\left(\log \mathrm{D}_{7.4}=1.44\right)[34,46,60]$. Although negatively charged compounds, and carboxylic acids in particular, are generally considered to be poor BBB penetrators [16], it is our opinion that this does not necessarily hold true for carborane-derived compounds. Carboranes with their intrinsic high hydrophobicity might be able to sufficiently counterbalance the negative charge of a carboxylic acid. This was indicated by the increase in lipophilicity of compound 5 of around one order of magnitude. We achieved an increase in lipophilicity without the esterification of the carboxylic acid, which was shown to lead to an "inverse GSM" [21], making the resulting compound unsuitable for AD treatment. A higher lipophilicity could render the compound more susceptible to passive transport through the BBB. However, the general transport mechanism of flurbiprofen and other NSAIDs with carboxyl groups is not fully understood. Thus, involvement of active transporters, such as the monocarboxylate transporter (MCT) family or the human organic anion transporter (hOAT) family, is discussed [61,62]. In contrast to that, Parepally et al. could find no evidence of a saturable transport of flurbiprofen through the $\mathrm{BBB}$, as it would be expected for a sole active transport mechanism [63]. Instead, they attributed the limitations of the transport through the BBB to the binding of flurbiprofen at bovine serum albumin (BSA), as rapid uptake of $\left[{ }^{3} \mathrm{H}\right]$ flurbiprofen was observed in vitro in the absence of BSA [63], since Goszczyński et al. could demonstrate that carboranes also show interactions with BSA [64], and the incorporation of meta-carborane into the flurbiprofen skeleton could even be of a disadvantage due to the higher plasma protein binding (PPB). However, it can be expected that replacement of the metabolically labile distal ring in flurbiprofen by the highly stable meta-carborane can prevent fast metabolic 
degradation at this ring and, thus, prolong the half-life of the drug, facilitating transfer through the BBB. This and the previous assumptions need to be further tested in future.

Another advantage of compound $\mathbf{5}$ is its low toxicity, which was determined by MTT and $\mathrm{CV}$ assays up to a concentration of $100 \mu \mathrm{M}$ on several human and rodent cell lines. In addition, the influence of different COX-1 or COX-2 expression levels on the cell lines could not be observed. This is in accordance with the fact that no inhibition of the two COX isoforms could be determined. Of note, especially the high $\mathrm{IC}_{50}$ values against the human glioblastoma cell lines LN229 and U251 suggest the potential use of compound 5 as a CNS-active compound. In addition, no obvious toxicity was observed in human HEK cells up to $150 \mu \mathrm{M}$ during the conducted GSM activity assays. Taken together, compound 5 provides a good toxicity profile for possible follow-up in vivo studies. In contrast, the carborane-analogues of the COX-2 selective inhibitors, celecoxib and rofecoxib, showed increased toxicity in the low micromolar range towards several cancer cell lines (A375, B16, B16-F10, and HCT116) $[65,66]$. This underlines that the site for introducing a carborane moiety has to be chosen carefully.

In summary, in a simple four-step synthetic sequence, a meta-carborane analogue of flurbiprofen was obtained in good overall yield. The derivatisation shifted the lipophilicity into a more favourable range required for BBB penetration. This could be achieved without diminishing the $\gamma$-secretase modulating activity. Especially, this last aspect of compound 5 underlines the benefit of the carborane moiety as phenyl mimetic in the development of potential $\mathrm{AD}$ drugs in future.

\section{Material and Methods}

\subsection{Determination of COX Inhibition}

COX inhibition potency against ovine COX-1 and human COX-2 was determined using the fluorescence-based COX assay "COX Fluorescent Inhibitor Screening Assay Kit" (catalog number 700100; Cayman Chemical Company, Ann Arbor, MI, USA) according to the manufacturer's instructions as previously reported by us [44].

\subsection{Determination of $\log D_{7.4}$}

The $\log \mathrm{D}$ measurements were conducted using the HPLC method originally described by Donovan et al. [45] and recently reported by us [44] on the HPLC system 1100 from Agilent Technologies with two different columns, a Chromolith SpeedROD RP-18E 50 from Merck and an Asahipak ODP-50 4B $4.6 \times 50$ from Shodex (Showa Denko Europe $\mathrm{GmbH}$, Munich, Germany). In both cases, the eluent consisted of methanol and a $0.01 \mathrm{M}$ phosphate buffer $(\mathrm{pH}=7.4)$; the applied gradient was $0 \mathrm{~min}$ at $70 \%$ methanol, $10 \mathrm{~min}$ at $100 \%$ methanol, $20 \mathrm{~min}$ at $100 \%$ methanol at a flow rate of $0.6 \mathrm{~mL} / \mathrm{min}$.

\subsection{Determination of Cytotoxicity}

Cytotoxicity was determined by conducting MTT and CV assays using cell viability as an indicator [67]. All measurements were carried out in triplicates.

\subsection{Determination of GSM Activity}

Nearly confluent $(80 \%) \mathrm{HEK} / \mathrm{sw}$ cells were treated with the indicated concentrations of compound 5 or flurbiprofen ( \pm -2-fluoro- $\alpha$-methyl-4-biphenylacetic acid; F8514, SigmaAldrich, St. Louis, MO, USA) as described before [55]. Cells treated with DMSO or $1 \mu \mathrm{M}$ GSM-1 were used as negative and positive controls, respectively. After overnight treatment, the conditioned medium was collected, cleared by centrifugation $\left(10 \mathrm{~min}, 4^{\circ} \mathrm{C}, 16,000 \times g\right)$, and the levels of secreted $A \beta 38, A \beta 40$, and $A \beta 42$ were analysed using an established $\mathrm{A} \beta$ species-specific sandwich immunoassay purchase from Meso Scale Discovery (MSD, Rockville, MD, USA) [54]. 


\subsection{Synthetic Methods}

\subsubsection{General Synthetic Information}

All syntheses were carried out under nitrogen atmosphere using Schlenk technique. The solvents dichloromethane (DCM) and diethyl ether were dried with a solvent purification system SPS-800 Series from MBraun; carbon tetrachloride was dried over phosphorus pentoxide under nitrogen atmosphere. meta-Carborane was purchased from Katchem Ltd. (Prague, Czech Republic). All other chemicals were purchased from common suppliers. 9-Iodo-1,7-dicarba-closo-dodecaborane(12) (1) was prepared according to the literature $[68,69]$.

NMR data were collected with either an Avance DRX-400 spectrometer $\left({ }^{1} \mathrm{H}-\mathrm{NMR}\right.$ $400.13 \mathrm{MHz},{ }^{13} \mathrm{C}\left\{{ }^{1} \mathrm{H}\right\}-\mathrm{NMR} 100.63 \mathrm{MHz},{ }^{11} \mathrm{~B}-\mathrm{NMR} 128.38 \mathrm{MHz}$ ) or an Ascend-400 spectrometer $\left({ }^{1} \mathrm{H}-\mathrm{NMR} 400.16 \mathrm{MHz},{ }^{13} \mathrm{C}\left\{{ }^{1} \mathrm{H}\right\}-\mathrm{NMR} 100.63 \mathrm{MHz},{ }^{11} \mathrm{~B}-\mathrm{NMR} 128.38 \mathrm{MHz}\right)$ from Bruker. ${ }^{1} \mathrm{H}$ - and ${ }^{13} \mathrm{C}$-NMR spectra were referenced to tetramethylsilane and the ${ }^{11} \mathrm{~B}-\mathrm{NMR}$ spectra to the $\Xi$ scale [70]. Deuterated solvents were purchased from EURISO-TOP with a deuteration rate of $99.80 \%$. All structural assignments of NMR signals were based on 2D NMR experiments, COSY, HSQC, HMQC and HMBC.

High-resolution ESI mass spectrometry was carried out on an Impact II from Bruker Daltonics and high-resolution EI mass spectrometry on an MAT 8230 from Finnigan (nowadays ThermoFisher Scientific, Waltham, MA, USA). The simulation of the mass spectra was conducted with a web-based program from Scientific Instrument Services Inc. (Palmer, MA, USA) [71].

The measurements of the IR spectra were carried out either on a Spektrum 2000 FT-IR from PerkinElmer (Waltham, MA, USA) with $\mathrm{KBr}$ pellets (KBr) or a Nicolette IS5 (ATR) from ThermoFisher (Waltham, MA, USA). The signal intensity was classified as weak (w), medium (m) or strong (s).

\subsubsection{Syntheses}

$$
\text { 9-(4-Ethylphenyl)-1,7-dicarba-closo-dodecaborane(12) (2) (Scheme 2) }
$$

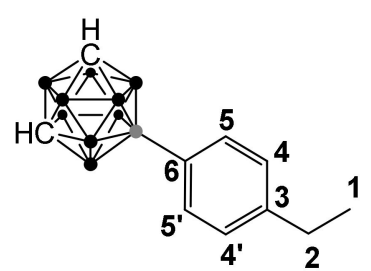

Scheme 2. 9-(4-Ethylphenyl)-1,7-dicarba-closo-dodecaborane(12) (2).

Magnesium turnings $(1.84 \mathrm{~g}, 75.65 \mathrm{mmol}, 7.0 \mathrm{eq})$ were heated to approximately $200{ }^{\circ} \mathrm{C}$ under high vacuum. After cooling to ambient temperature, $13 \mathrm{~mL} \mathrm{Et}{ }_{2} \mathrm{O}$ and $0.03 \mathrm{~mL}$ $(0.065 \mathrm{~g}, 0.35 \mathrm{mmol}, 0.03 \mathrm{eq})$ dibromoethane were added. Then, $10.00 \mathrm{~g}(54.04 \mathrm{mmol}, 5.0 \mathrm{eq})$ 4-ethylbromobenzene in $60 \mathrm{~mL} \mathrm{Et}_{2} \mathrm{O}$ was added dropwise at ambient temperature over $10 \mathrm{~min}$. The mixture was refluxed for one hour, forming a deep red-brown suspension. The solid was filtered off and the resulting red-brown solution was added dropwise over $20 \mathrm{~min}$

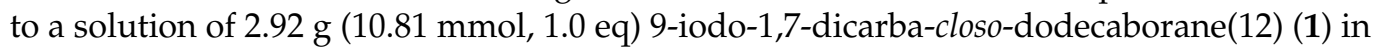
$60 \mathrm{~mL}$ THF at $0{ }^{\circ} \mathrm{C}$. After warming to ambient temperature, $50 \mathrm{~mL}$ THF, $0.38 \mathrm{~g}(0.54 \mathrm{mmol}$, $0.05 \mathrm{eq})\left[\mathrm{PdCl}_{2}\left(\mathrm{PPh}_{3}\right)_{2}\right]$ and $0.10 \mathrm{~g}(0.54 \mathrm{mmol}, 0.05 \mathrm{eq}) \mathrm{CuI}$ were added in one portion and the reaction mixture was refluxed for four days. The resulting black opaque mixture was cooled to $0{ }^{\circ} \mathrm{C}$ and the reaction quenched by adding $2 \mathrm{~N} \mathrm{HCl}$ solution. The phases were separated, and the organic phase was washed once with $200 \mathrm{~mL} \mathrm{H}_{2} \mathrm{O} /$ brine $(3 / 1(v / v))$. The organic phase was then dried over $\mathrm{MgSO}_{4}$, filtered and the solvent removed under reduced pressure. The product was purified by column chromatography with $n$-hexane over silica, yielding $2.28 \mathrm{~g}(9.17 \mathrm{mmol}, 85 \%)$ colourless crystals.

${ }^{1} \mathrm{H}-\mathrm{NMR}\left(\mathrm{CDCl}_{3}, 400 \mathrm{MHz}\right): \delta=1.23\left(3 \mathrm{H}, \mathrm{t},{ }^{1} \mathrm{~J}_{\mathrm{HH}}=7.6 \mathrm{~Hz}, \mathrm{H}-1\right), 1.50-3.50(9 \mathrm{H}, \mathrm{br}$, $\mathrm{BH}), 2.62\left(2 \mathrm{H}, \mathrm{q},{ }^{1} J_{\mathrm{HH}}=7.6 \mathrm{~Hz}, \mathrm{H}-2\right), 2.99\left(2 \mathrm{H}, \mathrm{br} \mathrm{s}, \mathrm{H}\right.$-carbon $\left.{ }_{\text {cluster }}\right), 7.12\left(2 \mathrm{H}, \mathrm{m}, \mathrm{H}-4 / 4^{\prime}\right)$, 
$7.44\left(2 \mathrm{H}, \mathrm{d},{ }^{1} J_{\mathrm{HH}}=7.6 \mathrm{~Hz}, \mathrm{H}-5 / 5^{\prime}\right) \mathrm{ppm} .{ }^{13} \mathrm{C}\left\{{ }^{1} \mathrm{H}\right\}-\mathrm{NMR}\left(\mathrm{CDCl}_{3}, 100 \mathrm{MHz}\right): \delta=15.4\left(\mathrm{CH}_{3}\right.$, C-1), $28.6\left(\mathrm{CH}_{2}, \mathrm{C}-2\right), 54.1$ (br, CH, C-cluster), $127.2\left(\mathrm{CH}, \mathrm{C}-4 / 4^{\prime}\right), 133.2\left(\mathrm{CH}, \mathrm{C}-5 / 5^{\prime}\right)$, $143.4(\mathrm{C}, \mathrm{C}-3) \mathrm{ppm}$. The signal of the quaternary carbon atom $\mathrm{C}-6$ could not be detected. ${ }^{11} \mathrm{~B}\left\{{ }^{1} \mathrm{H}\right\}-N M R\left(\mathrm{CDCl}_{3}, 128 \mathrm{MHz}\right): \delta=-20.0(1 \mathrm{~B}, \mathrm{~s}, \mathrm{BH}),-17.5(1 \mathrm{~B}, \mathrm{~s}, \mathrm{BH}),-13.7(2 \mathrm{~B}, \mathrm{~s}$, $\mathrm{BH}),-13.0(2 \mathrm{~B}, \mathrm{~s}, \mathrm{BH}),-9.6(1 \mathrm{~B}, \mathrm{~s}, \mathrm{BH}),-6.5(2 \mathrm{~B}, \mathrm{~s}, \mathrm{BH})$ and $0.5(1 \mathrm{~B}, \mathrm{~s}, \mathrm{BC}) \mathrm{ppm} .{ }^{11} \mathrm{~B}-\mathrm{NMR}$ $\left(\mathrm{CDCl}_{3}, 128 \mathrm{MHz}\right): \delta=-20.0\left(1 \mathrm{~B}, \mathrm{~d},{ }^{1} J_{\mathrm{BH}}=181 \mathrm{~Hz}, \mathrm{BH}\right),-17.5\left(1 \mathrm{~B}, \mathrm{~d},{ }^{1} J_{\mathrm{BH}}=181 \mathrm{~Hz}, \mathrm{BH}\right)$, -15.5 to $-11.5(4 \mathrm{~B}, \mathrm{br}, \mathrm{BH}),-9.6\left(1 \mathrm{~B}, \mathrm{~d},{ }^{1} J_{\mathrm{BH}}=154 \mathrm{~Hz}, \mathrm{BH}\right),-6.5\left(2 \mathrm{~B}, \mathrm{~d},{ }^{1} J_{\mathrm{BH}}=162 \mathrm{~Hz}, \mathrm{BH}\right)$ and 0.5 (1B, s, BC) ppm. HREIMS: $m / z 248.257$ (calculated for $\mathrm{C}_{10} \mathrm{H}_{20} \mathrm{~B}_{10}: m / z$ 248.257). IR: $\tilde{\mathrm{v}}(\mathrm{ATR})=3050(\mathrm{~s}), 2962(\mathrm{w}), 2591(\mathrm{~s}, \mathrm{BH}), 1604(\mathrm{w}), 1507(\mathrm{w}), 1457(\mathrm{w}), 1435(\mathrm{w}), 1400(\mathrm{w})$, $1229(\mathrm{w}), 1184(\mathrm{w}), 1158(\mathrm{w}), 1064(\mathrm{~m}), 1028(\mathrm{~m}), 988(\mathrm{w}), 867(\mathrm{w}), 845(\mathrm{~m}), 829(\mathrm{w})$ and $812(\mathrm{w}) \mathrm{cm}^{-1}$. 9-[4-(1-Bromoethyl)phenyl]-1,7-dicarba-closo-dodecaborane(12) (3) (Scheme 3)

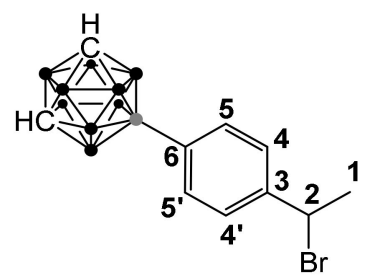

Scheme 3. 9-[4-(1-Bromoethyl)phenyl]-1,7-dicarba-closo-dodecaborane(12) (3).

Compound $2(0.30 \mathrm{~g}, 1.21 \mathrm{mmol}, 1.0 \mathrm{eq})$ and $0.22 \mathrm{~g}$ (1.21 mmol, $1.0 \mathrm{eq})$ NBS were suspended in $20 \mathrm{~mL} \mathrm{CCl}_{4}$. The mixture was irradiated with a $500 \mathrm{~W}$ halogen lamp for $45 \mathrm{~min}$, causing the solvent to boil slightly. After cooling to ambient temperature, a precipitate formed, which was filtered off. The resulting clear solution was evaporated. The resulting oil (compound 3) was directly used for the next step, without any further purification.

${ }^{1} \mathrm{H}-\mathrm{NMR}\left(\mathrm{CDCl}_{3}, 400 \mathrm{MHz}\right): \delta=1.50-3.50(9 \mathrm{H}, \mathrm{br}, \mathrm{BH}), 2.04\left(3 \mathrm{H}, \mathrm{d},{ }^{3} \mathrm{~J}_{\mathrm{HH}}=6.9 \mathrm{~Hz}, \mathrm{H}-1\right)$, $3.01\left(2 \mathrm{H}, \mathrm{br} \mathrm{s}, \mathrm{H}\right.$-carbon cluster $\left._{1}\right), 5.21\left(1 \mathrm{H}, \mathrm{q},{ }^{3} \mathrm{~J}_{\mathrm{HH}}=6.9 \mathrm{~Hz}, \mathrm{H}-2\right), 7.34\left(2 \mathrm{H}, \mathrm{d},{ }^{3} J_{\mathrm{HH}}=8.1 \mathrm{~Hz}\right.$, $\left.\left.\mathrm{H}-4 / 4^{\prime}\right), 7.44\left(2 \mathrm{H}, \mathrm{d},{ }^{1} J_{\mathrm{HH}}=7.9 \mathrm{~Hz}, \mathrm{H}-5 / 5^{\prime}\right) \mathrm{ppm} .{ }^{13} \mathrm{C}^{1}{ }^{1} \mathrm{H}\right\}-\mathrm{NMR}\left(\mathrm{CDCl}_{3}, 100 \mathrm{MHz}\right): \delta=26.7$ $\left(\mathrm{CH}_{3}, \mathrm{C}-1\right), 50.0(\mathrm{CH}, \mathrm{C}-2), 54.3\left(\mathrm{CH}, \mathrm{C}_{\mathrm{Cluster}}\right), 125.9\left(\mathrm{CH}, \mathrm{C}-4 / 4^{\prime}\right), 133.5\left(\mathrm{CH}, \mathrm{C}-5 / 5^{\prime}\right)$ and 142.2 (C, C-3) ppm. The signal of the quaternary carbon $\mathrm{C}-6$ could not be detected. ${ }^{11} \mathrm{~B}\left\{{ }^{1} \mathrm{H}\right\}-$ $\operatorname{NMR}\left(\mathrm{CDCl}_{3}, 128 \mathrm{MHz}\right): \delta=-19.7(1 \mathrm{~B}, \mathrm{~s}, \mathrm{BH}),-17.4(1 \mathrm{~B}, \mathrm{~s}, \mathrm{BH}),-13.8(2 \mathrm{~B}, \mathrm{~s}, \mathrm{BH}),-13.0$ $(2 \mathrm{~B}, \mathrm{~s}, \mathrm{BH}),-9.6(1 \mathrm{~B}, \mathrm{~s}, \mathrm{BH}),-6.5(2 \mathrm{~B}, \mathrm{~s}, \mathrm{BH})$ and $0.2(1 \mathrm{~B}, \mathrm{~s}, \mathrm{BC}) \mathrm{ppm} .{ }^{11} \mathrm{~B}-\mathrm{NMR}\left(\mathrm{CDCl}_{3}\right.$, $128 \mathrm{MHz}): \delta=-19.7\left(1 \mathrm{~B}, \mathrm{~d},{ }^{1} J_{\mathrm{BH}}=186 \mathrm{~Hz}, \mathrm{BH}\right),-17.4\left(1 \mathrm{~B}, \mathrm{~d},{ }^{1} J_{\mathrm{BH}}=181 \mathrm{~Hz}, \mathrm{BH}\right),-15.5$ to $-11.5(4 \mathrm{~B}, \mathrm{br}, \mathrm{BH}),-9.6\left(1 \mathrm{~B}, \mathrm{~d},{ }^{1} J_{\mathrm{BH}}=152 \mathrm{~Hz}, \mathrm{BH}\right),-6.5\left(2 \mathrm{~B}, \mathrm{~d},{ }^{1} J_{\mathrm{BH}}=163 \mathrm{~Hz}, \mathrm{BH}\right)$ and 0.2 (1B, s, BC) ppm. HRESI: $m / z 326.15803$ (calculated for $\mathrm{C}_{10} \mathrm{H}_{18} \mathrm{~B}_{10} \mathrm{Br}: \mathrm{m} / \mathrm{z} 326.15805$ ).

9-[4-(1-Cyanoethyl)phenyl]-1,7-dicarba-closo-dodecaborane(12) (4) (Scheme 4)

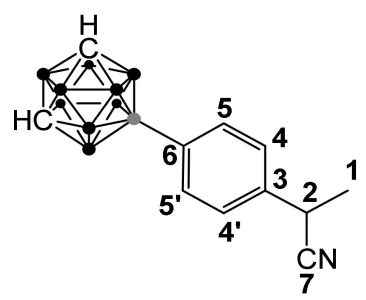

Scheme 4. 9-[4-(1-Cyanoethyl)phenyl]-1,7-dicarba-closo-dodecaborane(12) (4).

Crude $3(0.08 \mathrm{~g})$ and $0.19 \mathrm{~g}(1.88 \mathrm{mmol})$ trimethylsilylcyanide were dissolved in $15 \mathrm{~mL}$ DCM. The solution was cooled to $0{ }^{\circ} \mathrm{C}$ and $0.25 \mathrm{~mL}(0.56 \mathrm{~g}$, $2.14 \mathrm{mmol}) \mathrm{SnCl}_{4}$ were added rapidly but dropwise. The resulting brown mixture was stirred at $0{ }^{\circ} \mathrm{C}$ for $20 \mathrm{~min}$ and then at ambient temperature for $2.5 \mathrm{~h}$. The reaction was quenched with saturated $\mathrm{Na}_{2} \mathrm{CO}_{3}$ solution and the resulting mixture diluted with $50 \mathrm{~mL} \mathrm{DCM}$ and $50 \mathrm{~mL}$ water. The two phases were separated and the aqueous phase was extracted with $50 \mathrm{~mL}$ DCM. 
The combined organic phases were dried over $\mathrm{MgSO}_{4}$, filtered and the solvent removed under reduced pressure. The product was purified by column chromatography, using $n$-hexane/ethylacetate mixtures as eluent. Yield $0.04 \mathrm{~g}(0.15 \mathrm{mmol}, 99 \%$ over two steps $)$.

${ }^{1} \mathrm{H}-\mathrm{NMR}\left(\mathrm{CDCl}_{3}, 400 \mathrm{MHz}\right): \delta=1.60-3.50(9 \mathrm{H}, \mathrm{br}, \mathrm{BH}), 1.63\left(3 \mathrm{H}, \mathrm{d},{ }^{3} J_{\mathrm{HH}}=7.3 \mathrm{~Hz}, \mathrm{H}-1\right)$, $3.02(2 \mathrm{H}, \mathrm{br} \mathrm{s}, \mathrm{H}$-carbon cluster $), 3.86\left(1 \mathrm{H}, \mathrm{q},{ }^{3} \mathrm{~J}_{\mathrm{HH}}=7.3 \mathrm{~Hz}, \mathrm{H}-2\right), 7.25\left(2 \mathrm{H}, \mathrm{d},{ }^{3} J_{\mathrm{HH}}=8.0 \mathrm{~Hz}\right.$, $\left.\mathrm{H}-4 / 4^{\prime}\right)$ and $7.52\left(2 \mathrm{H}, \mathrm{d},{ }^{3} J_{\mathrm{HH}}=7.7 \mathrm{~Hz}, \mathrm{H}-5 / 5^{\prime}\right) \mathrm{ppm} .{ }^{13} \mathrm{C}\left\{{ }^{1} \mathrm{H}\right\}-\mathrm{NMR}\left(\mathrm{CDCl}_{3}, 100 \mathrm{MHz}\right)$ : $\delta=21.4\left(\mathrm{CH}_{3}, \mathrm{C}-1\right), 31.1(\mathrm{CH}, \mathrm{C}-2), 54.4\left(\mathrm{CH}, \mathrm{C}_{\text {Cluster }}\right), 121.7(\mathrm{C}, \mathrm{C}-7), 125.9\left(\mathrm{CH}, \mathrm{C}-4 / 4^{\prime}\right)$, $133.9\left(\mathrm{CH}, \mathrm{C}-5 / 5^{\prime}\right)$ and $136.1(\mathrm{C}, \mathrm{C}-3) \mathrm{ppm}$. The signal of the quaternary carbon $\mathrm{C}-6$ could not be detected. ${ }^{11} \mathrm{~B}\left\{{ }^{1} \mathrm{H}\right\}-\mathrm{NMR}\left(\mathrm{CDCl}_{3}, 128 \mathrm{MHz}\right): \delta=-19.6(1 \mathrm{~B}, \mathrm{~s}, \mathrm{BH}),-17.4(1 \mathrm{~B}, \mathrm{~s}, \mathrm{BH})$, $-13.7(2 \mathrm{~B}, \mathrm{~s}, \mathrm{BH}),-13.0(2 \mathrm{~B}, \mathrm{~s}, \mathrm{BH}),-9.6(1 \mathrm{~B}, \mathrm{~s}, \mathrm{BH}),-6.5(2 \mathrm{~B}, \mathrm{~s}, \mathrm{BH})$ and $0.2(1 \mathrm{~B}, \mathrm{~s}, \mathrm{BC})$ ppm. ${ }^{11} \mathrm{~B}-\mathrm{NMR}\left(\mathrm{CDCl}_{3}, 128 \mathrm{MHz}\right): \delta=-19.6\left(1 \mathrm{~B}, \mathrm{~d},{ }^{1} J_{\mathrm{BH}}=180 \mathrm{~Hz}, \mathrm{BH}\right),-17.4(1 \mathrm{~B}, \mathrm{~d}$, $\left.{ }^{1} J_{\mathrm{BH}}=181 \mathrm{~Hz}, \mathrm{BH}\right),-13.7\left(2 \mathrm{~B}, \mathrm{~d},{ }^{1} J_{\mathrm{BH}}=167 \mathrm{~Hz}, \mathrm{BH}\right),-13.0\left(2 \mathrm{~B}, \mathrm{~d},{ }^{1} J_{\mathrm{BH}}=159 \mathrm{~Hz}, \mathrm{BH}\right)$, $-9.6\left(1 \mathrm{~B}, \mathrm{~d},{ }^{1} J_{\mathrm{BH}}=152 \mathrm{~Hz}, \mathrm{BH}\right),-6.5\left(2 \mathrm{~B}, \mathrm{~d},{ }^{1} J_{\mathrm{BH}}=163 \mathrm{~Hz}, \mathrm{BH}\right)$ and $0.2(1 \mathrm{~B}, \mathrm{~s}, \mathrm{BC}) \mathrm{ppm}$. HRESI: $m / z 296.242$ (calculated for $\mathrm{C}_{11} \mathrm{H}_{19} \mathrm{~B}_{10} \mathrm{NNa}: m / z 296.241$ ). IR: $\tilde{\mathrm{v}}(\mathrm{KBr})=3062(\mathrm{~s})$, $2995(\mathrm{w}), 2944(\mathrm{w}), 2878(\mathrm{w}), 2601(\mathrm{~s}, \mathrm{BH}), 2245(\mathrm{w}), 1510(\mathrm{w}), 1454(\mathrm{w}), 1398(\mathrm{~m}), 1229(\mathrm{~m})$, $1159(\mathrm{w}), 1063(\mathrm{~m}), 1032(\mathrm{~m}), 991(\mathrm{~m}), 945(\mathrm{w}), 879(\mathrm{~m}), 839(\mathrm{~m}), 813(\mathrm{w})$ and $729(\mathrm{~m}) \mathrm{cm}^{-1}$.

2-[4-(1,7-Dicarba-closo-dodecaboran-9-yl(12))phenyl]propionic acid (5) and 2-[4-(1,7dicarba-closo-dodecaboran-9-yl(12))phenyl]propanamide (6) (Scheme 5).

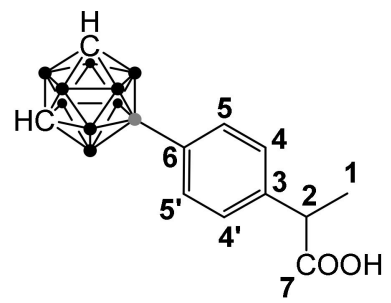

(5)

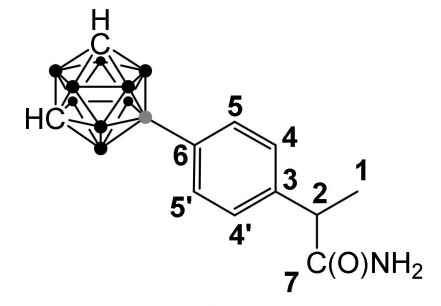

(6)

Scheme 5. 2-[4-(1,7-Dicarba-closo-dodecaboran-9-yl(12))phenyl]propionic acid (5) and 2-[4-(1,7dicarba-closo-dodecaboran-9-yl(12))phenyl]propanamide (6).

Compound 4 ( $0.017 \mathrm{~g}, 0.063 \mathrm{mmol}, 1.0 \mathrm{eq})$ was suspended in $6 \mathrm{~mL} \mathrm{AcOH}$ conc. $/ \mathrm{HCl}_{\mathrm{aq} . \text {, conc. }}$ $(5 / 1(v / v))$ and the resulting mixture was stirred under reflux for one hour and then at ambient temperature for three days. The clear solution was diluted with $50 \mathrm{~mL}$ water and extracted with $50 \mathrm{~mL}$ ethyl acetate. The phases were separated, and the organic phase was washed once with $50 \mathrm{~mL}$ water. The organic phase was dried over $\mathrm{MgSO}_{4}$, filtered and the solvent was removed under reduced pressure. The product was purified by column chromatography using $n$-hexane/ethyl acetate mixtures as eluent. Yield $0.007 \mathrm{~g}$ $(0.023 \mathrm{mmol}, 36 \%)$. In addition, $0.007 \mathrm{~g}(0.024 \mathrm{mmol}, 38 \%)$ of the partially hydrolysed compounds, 2-[4-(1,7-dicarba-closo-dodecaboran-9-yl(12))phenyl]propanamide (6), could be isolated.

Analytical data of 5

${ }^{1} \mathrm{H}-\mathrm{NMR}\left(\mathrm{CDCl}_{3}, 400 \mathrm{MHz}\right): \delta=1.50\left(3 \mathrm{H}, \mathrm{d},{ }^{3} \mathrm{~J}_{\mathrm{HH}}=7.2 \mathrm{~Hz}, \mathrm{H}-1\right), 1.50-3.50(9 \mathrm{H}$, br, BH), $3.00(2 \mathrm{H}, \mathrm{br} \mathrm{s}, \mathrm{H}$-carbon cluster $), 3.71\left(1 \mathrm{H}, \mathrm{q},{ }^{3} \mathrm{~J}_{\mathrm{HH}}=7.2 \mathrm{~Hz}, \mathrm{H}-2\right), 7.22(2 \mathrm{H}, \mathrm{d}$, $\left.{ }^{3} J_{\mathrm{HH}}=8.0 \mathrm{~Hz}, \mathrm{H}-4 / 4^{\prime}\right), 7.50\left(2 \mathrm{H}, \mathrm{d},{ }^{3} J_{\mathrm{HH}}=7.9 \mathrm{~Hz}, \mathrm{H}-5 / 5^{\prime}\right)$ and $10.5(1 \mathrm{H}, \mathrm{br} \mathrm{s}, \mathrm{COOH}) \mathrm{ppm}$. $\left.{ }^{13} \mathrm{C}_{\{}{ }^{1} \mathrm{H}\right\}-\mathrm{NMR}\left(\mathrm{CDCl}_{3}, 100 \mathrm{MHz}\right): \delta=18.1\left(\mathrm{CH}_{3}, \mathrm{C}-1\right), 45.1(\mathrm{CH}, \mathrm{C}-2), 54.2\left(\mathrm{CH}, \mathrm{C}_{\mathrm{Cluster}}\right)$, $126.8\left(\mathrm{CH}, \mathrm{C}-4 / 4^{\prime}\right), 133.5\left(\mathrm{CH}, \mathrm{C}-5 / 5^{\prime}\right), 138.8(\mathrm{C}, \mathrm{C}-3)$ and $180.1(\mathrm{C}-7) \mathrm{ppm}$. The signal of the quaternary carbon $\mathrm{C}-6$ could not be detected. ${ }^{11} \mathrm{~B}\left\{{ }^{1} \mathrm{H}\right\}-\mathrm{NMR}\left(\mathrm{CDCl}_{3}, 128 \mathrm{MHz}\right)$ : $\delta=-19.7(1 \mathrm{~B}, \mathrm{~s}, \mathrm{BH}),-17.4(1 \mathrm{~B}, \mathrm{~s}, \mathrm{BH}),-13.8(2 \mathrm{~B}, \mathrm{~s}, \mathrm{BH}),-13.0(2 \mathrm{~B}, \mathrm{~s}, \mathrm{BH}),-9.6(1 \mathrm{~B}, \mathrm{~s}$, $\mathrm{BH}),-6.5(2 \mathrm{~B}, \mathrm{~s}, \mathrm{BH})$ and $0.31(1 \mathrm{~B}, \mathrm{~s}, \mathrm{BC}) \mathrm{ppm} .{ }^{11} \mathrm{~B}-\mathrm{NMR}\left(\mathrm{CDCl}_{3}, 128 \mathrm{MHz}\right): \delta=-19.7$ $\left(1 \mathrm{~B}, \mathrm{~d},{ }^{1} J_{\mathrm{BH}}=195 \mathrm{~Hz}, \mathrm{BH}\right),-17.5\left(1 \mathrm{~B}, \mathrm{~d},{ }^{1} J_{\mathrm{BH}}=182 \mathrm{~Hz}, \mathrm{BH}\right),-15.5$ to $-11.0(4 \mathrm{~B}, \mathrm{br}, \mathrm{BH})$, $-9.6\left(1 \mathrm{~B}, \mathrm{~d},{ }^{1} J_{\mathrm{BH}}=151 \mathrm{~Hz}, \mathrm{BH}\right),-6.5\left(2 \mathrm{~B}, \mathrm{~d},{ }^{1} \mathrm{~J}_{\mathrm{BH}}=163 \mathrm{~Hz}, \mathrm{BH}\right)$ and $0.31(1 \mathrm{~B}, \mathrm{~s}, \mathrm{BC}) \mathrm{ppm}$. HRESI: $m / z 315.237$ (calculated for $\mathrm{C}_{11} \mathrm{H}_{20} \mathrm{~B}_{10} \mathrm{NaO}_{2}: m / z$ 315.236). IR: $\tilde{\mathrm{v}}(\mathrm{KBr})=1377(\mathrm{w})$, $1283(\mathrm{~m}), 1252(\mathrm{~m}), 1228(\mathrm{~s}), 1156(\mathrm{w}), 1071(\mathrm{~m}), 1031(\mathrm{w}), 921(\mathrm{~m}), 867(\mathrm{~s}), 796(\mathrm{~m}), 740(\mathrm{w})$, $726(\mathrm{~m})$ and $668(\mathrm{~m}) \mathrm{cm}^{-1}$.

Analytical data of 6 
${ }^{1} \mathrm{H}-\mathrm{NMR}\left(\mathrm{CDCl}_{3}, 400 \mathrm{MHz}\right): \delta=1.52\left(3 \mathrm{H}, \mathrm{d},{ }^{3} \mathrm{~J}_{\mathrm{HH}}=7.2 \mathrm{~Hz}, \mathrm{H}-1\right), 1.50-3.50(9 \mathrm{H}$, br, BH), $3.02($ br s, $2 \mathrm{H}, \mathrm{H}$-carbon Cluster $), 3.58\left(1 \mathrm{H}, \mathrm{q},{ }^{3} \mathrm{~J}_{\mathrm{HH}}=7.2 \mathrm{~Hz}, \mathrm{H}-2\right), 5.34(2 \mathrm{H}, \mathrm{br} \mathrm{s}$, $\left.\mathrm{NH}_{2}\right), 7.21\left(2 \mathrm{H}, \mathrm{d},{ }^{3} J_{\mathrm{HH}}=8.0 \mathrm{~Hz}, \mathrm{H}-4 / 4^{\prime}\right)$ and $7.49\left(2 \mathrm{H}, \mathrm{d},{ }^{3} J_{\mathrm{HH}}=7.7 \mathrm{~Hz}, \mathrm{H}-5 / 5^{\prime}\right) \mathrm{ppm}$. $\left.{ }^{13} \mathrm{C}^{1}{ }^{1} \mathrm{H}\right\}-\mathrm{NMR}\left(\mathrm{CDCl}_{3}, 100 \mathrm{MHz}\right): \delta=18.2\left(\mathrm{CH}_{3}, \mathrm{C}-1\right), 46.4(\mathrm{CH}, \mathrm{C}-2), 54.3\left(\mathrm{CH}, \mathrm{C}_{\mathrm{Cluster}}\right)$, $126.9\left(\mathrm{CH}, \mathrm{C}-4 / 4^{\prime}\right), 133.8\left(\mathrm{CH}, \mathrm{C}-5 / 5^{\prime}\right), 140.2(\mathrm{C}, \mathrm{C}-3)$ and $176.7(\mathrm{C}-7) \mathrm{ppm}$. The signal of the quaternary carbon $\mathrm{C}-6$ could not be detected. ${ }^{11} \mathrm{~B}\left\{{ }^{1} \mathrm{H}\right\}-\mathrm{NMR}\left(\mathrm{CDCl}_{3}, 128 \mathrm{MHz}\right)$ : $\delta=-19.7(1 \mathrm{~B}, \mathrm{~s}, \mathrm{BH}),-17.4(1 \mathrm{~B}, \mathrm{~s}, \mathrm{BH}),-13.8(2 \mathrm{~B}, \mathrm{~s}, \mathrm{BH}),-13.0(2 \mathrm{~B}, \mathrm{~s}, \mathrm{BH}),-9.6(1 \mathrm{~B}, \mathrm{~s}$, $\mathrm{BH}),-6.5(2 \mathrm{~B}, \mathrm{~s}, \mathrm{BH})$ and $0.23(1 \mathrm{~B}, \mathrm{~s}, \mathrm{BC}) \mathrm{ppm} .{ }^{11} \mathrm{~B}-\mathrm{NMR}\left(\mathrm{CDCl}_{3}, 128 \mathrm{MHz}\right): \delta=-19.7$ $\left(1 \mathrm{~B}, \mathrm{~d},{ }^{1} J_{\mathrm{BH}}=178 \mathrm{~Hz}, \mathrm{BH}\right),-17.5\left(1 \mathrm{~B}, \mathrm{~d},{ }^{1} J_{\mathrm{BH}}=181 \mathrm{~Hz}, \mathrm{BH}\right),-15.5$ to $-11.0(4 \mathrm{~B}, \mathrm{br}, \mathrm{BH})$, $-9.6\left(1 \mathrm{~B}, \mathrm{~d},{ }^{1} J_{\mathrm{BH}}=151 \mathrm{~Hz}, \mathrm{BH}\right),-6.5\left(2 \mathrm{~B}, \mathrm{~d},{ }^{1} J_{\mathrm{BH}}=163 \mathrm{~Hz}, \mathrm{BH}\right)$ and $0.23(1 \mathrm{~B}, \mathrm{~s}, \mathrm{BC}) \mathrm{ppm}$. HRESI: $m / z 314.252$ (calculated for $\mathrm{C}_{11} \mathrm{H}_{21} \mathrm{~B}_{10} \mathrm{NNaO}: \mathrm{m} / z$ 314.252).

Author Contributions: Conceptualization, S.S., H.S. and E.H.-H.; methodology, G.B., L.U., M.L.; validation, S.S., J.T., D.M.-I., D.D. and J.P.; formal analysis, G.B., M.L., D.M.-I., D.D.; resources, J.P., H.S., D.M.-I. and E.H.-H.; writing-original draft preparation, S.S.; writing-review and editing, all authors; visualisation, S.S. and J.T.; supervision, H.S., E.H.-H.; project administration, S.S., E.H.H.; funding acquisition, E.H.-H. All authors have read and agreed to the published version of the manuscript.

Funding: Support from the Deutscher Akademischer Austauschdienst (DAAD, doctoral fellowship for L.U.), the DFG (HE 1376/38-1 and STE 847/6-1), the Graduate School BuildMoNa (S.S., L.U.) and the Ministry of Education, Science and Technological Development of the Republic of Serbia (451-0368/2020-14/200007) is gratefully acknowledged. M.L. and J.P. thank the Helmholtz Association for funding a part of this work through the Helmholtz Cross-Programme Initiative "Technology and Medicine-Adaptive Systems".

Data Availability Statement: The data presented in this study is contained within the article or is available on request from the corresponding author.

Acknowledgments: The authors wish to thank Ralf Hoffmann and Daniela Volke of the Faculty of Chemistry and Mineralogy, Institute of Bioanalytical Chemistry, Leipzig University, Germany, for their scientific contribution and helpful discussions.

Conflicts of Interest: The authors declare no conflict of interest.

Sample Availability: Samples of the compounds are not available from the authors.

\section{References}

1. Cummings, J.L. Alzheimer's Disease. N. Engl. J. Med. 2004, 351, 56-67. [CrossRef]

2. Long, J.M.; Holtzman, D.M. Alzheimer Disease: An Update on Pathobiology and Treatment Strategies. Cell 2019, 179, 312-339. [CrossRef] [PubMed]

3. Steiner, H.; Fukumori, A.; Tagami, S.; Okochi, M. Making the Final Cut: Pathogenic Amyloid- $\beta$ Peptide Generation by $\gamma$-Secretase. Cell Stress 2018, 2, 292-310. [CrossRef]

4. Selkoe, D.J.; Hardy, J. The Amyloid Hypothesis of Alzheimer's Disease at 25 Years. EMBO Mol. Med. 2016, 8, 595-608. [CrossRef]

5. Jurisch-Yaksi, N.; Sannerud, R.; Annaert, W. A Fast Growing Spectrum of Biological Functions of $\gamma$-Secretase in Development and Disease. Biochim. Biophys. Acta Biomembr. 2013, 1828, 2815-2827. [CrossRef]

6. Doody, R.S.; Raman, R.; Farlow, M.; Iwatsubo, T.; Vellas, B.; Joffe, S.; Kieburtz, K.; He, F.; Sun, X.; Thomas, R.G.; et al. A Phase 3 Trial of Semagacestat for Treatment of Alzheimer's Disease. N. Engl. J. Med. 2013, 369, 341-350. [CrossRef] [PubMed]

7. Henley, D.B.; Sundell, K.L.; Sethuraman, G.; Dowsett, S.A.; May, P.C. Safety Profile of Semagacestat, a Gamma-secretase Inhibitor: IDENTITY trial findings. Curr. Med. Res. Opin. 2014, 30, 2021-2032. [CrossRef] [PubMed]

8. De Strooper, B. Lessons from a Failed $\gamma$-Secretase Alzheimer Trial. Cell 2014, 159, 721-726. [CrossRef] [PubMed]

9. Weggen, S.; Eriksen, J.L.; Das, P.; Sagi, S.A.; Wang, R.; Pietrzik, C.U.; Findlay, K.A.; Smith, T.E.; Murphy, M.P.; Bulter, T.; et al. A Subset of NSAIDs Lower Amyloidogenic A $\beta 42$ Independently of Cyclooxygenase Activity. Nature 2001, 414, 212-216. [CrossRef] [PubMed]

10. Xia, W. $\gamma$-Secretase and its Modulators: Twenty Years and Beyond. Neurosci. Lett. 2019, 701, 162-169. [CrossRef]

11. Bursavich, M.G.; Harrison, B.A.; Blain, J.-F. Gamma Secretase Modulators: New Alzheimer's Drugs on the Horizon? J. Med. Chem. 2016, 59, 7389-7409. [CrossRef]

12. Eriksen, J.L.; Sagi, S.A.; Smith, T.E.; Weggen, S.; Das, P.; McLendon, D.C.; Ozols, V.V.; Jessing, K.W.; Zavitz, K.H.; Koo, E.H.; et al. NSAIDs and Enantiomers of Flurbiprofen Target $\gamma$-Secretase and Lower A $\beta 42$ in vivo. J. Clin. Investig. 2003, 112, 440-449. [CrossRef] [PubMed] 
13. Wilcock, G.K.; Black, S.E.; Hendrix, S.B.; Zavitz, K.H.; Swabb, E.A.; Laughlin, M.A. Efficacy and Safety of Tarenflurbil in Mild to Moderate Alzheimer's Disease: A Randomised Phase II Trial. Lancet Neurol. 2008, 7, 483-493. [CrossRef]

14. Green, R.C. Effect of Tarenflurbil on Cognitive Decline and Activities of Daily Living in Patients with Mild Alzheimer Disease: A Randomized Controlled Trial. J. Am. Med. Assoc. 2009, 302, 2557. [CrossRef]

15. Imbimbo, B.P. Why Did Tarenflurbil Fail in Alzheimer's Disease? J. Alzheimer's Dis. 2009, 17, 757-760. [CrossRef]

16. Clark, D.E. In Silico Prediction of Blood-Brain Barrier Permeation. Drug Discov. Today 2003, 8, 927-933. [CrossRef]

17. Dichiara, M.; Amata, B.; Turnaturi, R.; Marrazzo, A.; Amata, E. Tuning Properties for Blood-Brain Barrier Permeation: A Statistics-Based Analysis. ACS Chem. Neurosci. 2020, 11, 34-44. [CrossRef]

18. Kaiser, D.G.; Brooks, C.D.; Lomen, P.L. Pharmacokinetics of Flurbiprofen. Am. J. Med. 1986, 80, 10-15. [CrossRef]

19. Tracy, T.S.; Marra, C.; Wrighton, S.A.; Gonzalez, F.J.; Korzekwa, K.R. Studies of Flurbiprofen 4'-Hydroxylation. Additional Evidence Suggesting the Sole Involvement of Cytochrome P450-2C9. Biochem. Pharmacol. 1996, 52, 1305-1309. [CrossRef]

20. Peretto, I.; Radaelli, S.; Parini, C.; Zandi, M.; Raveglia, L.F.; Dondio, G.; Fontanella, L.; Misiano, P.; Bigogno, C.; Rizzi, A.; et al. Synthesis and Biological Activity of Flurbiprofen Analogues as Selective Inhibitors of $\beta$-Amyloid $1-42$ Secretion. J. Med. Chem. 2005, 48, 5705-5720. [CrossRef]

21. Abdul-Hay, S.O.; Edirisinghe, P.; Thatcher, G.R.J. Selective Modulation of Amyloid- $\beta$ Peptide Degradation by Flurbiprofen, Fenofibrate, and Related Compounds Regulates A $\beta$ Levels. J. Neurochem. 2009, 111, 683-695. [CrossRef] [PubMed]

22. Kukar, T.L.; Ladd, T.B.; Bann, M.A.; Fraering, P.C.; Narlawar, R.; Maharvi, G.M.; Healy, B.; Chapman, R.; Welzel, A.T.; Price, R.W.; et al. Substrate-Targeting $\gamma$-Secretase Modulators. Nature 2008, 453, 925-929. [CrossRef]

23. Scholz, M.; Hey-Hawkins, E. Carbaboranes as Pharmacophores: Properties, Synthesis, and Application Strategies. Chem. Rev. 2011, 111, 7035-7062. [CrossRef] [PubMed]

24. Schleyer, P.v.R.; Najafian, K. Stability and Three-Dimensional Aromaticity of closo-Monocarbaborane $\mathrm{Anions}, \mathrm{CB}_{\mathrm{n}-1} \mathrm{H}_{\mathrm{n}}{ }^{-}$, and closo-Dicarboranes, $\mathrm{C}_{2} \mathrm{~B}_{\mathrm{n}-2} \mathrm{H}_{\mathrm{n}}$. Inorg. Chem. 1998, 37, 3454-3470. [CrossRef]

25. Grimes, R.N. Carboranes, 3rd ed.; Academic Press Inc.: Amsterdam, The Netherlands, 2016; ISBN 9780128018941.

26. Stockmann, P.; Gozzi, M.; Kuhnert, R.; Sárosi, M.B.; Hey-Hawkins, E. New Keys for Old Locks: Carborane-Containing Drugs as Platforms for Mechanism-Based Therapies. Chem. Soc. Rev. 2019, 48, 3497-3512. [CrossRef]

27. Tse, E.G.; Houston, S.D.; Williams, C.M.; Savage, G.P.; Rendina, L.M.; Hallyburton, I.; Anderson, M.; Sharma, R.; Walker, G.S.; Obach, R.S.; et al. Nonclassical Phenyl Bioisosteres as Effective Replacements in a Series of Novel Open-Source Antimalarials. J. Med. Chem. 2020, 63, 11585-11601. [CrossRef]

28. Gabel, D. Boron Clusters in Medicinal Chemistry: Perspectives and Problems. Pure Appl. Chem. 2015, 87, 173-179. [CrossRef]

29. Satapathy, R.; Dash, B.P.; Maguire, J.A.; Hosmane, N.S. New Developments in the Medicinal Chemistry of Carboranes. Collect. Czechoslov. Chem. Commun. 2010, 75, 995-1022. [CrossRef]

30. Ali, F.; S Hosmane, N.; Zhu, Y. Boron Chemistry for Medical Applications. Molecules 2020, 25, 828. [CrossRef]

31. Issa, F.; Kassiou, M.; Rendina, L.M. Boron in Drug Discovery: Carboranes as Unique Pharmacophores in Biologically Active Compounds. Chem. Rev. 2011, 111, 5701-5722. [CrossRef]

32. Gozzi, M.; Schwarze, B.; Hey-Hawkins, E. Half- and Mixed-Sandwich Metallacarboranes for Potential Applications in Medicine. Pure Appl. Chem. 2019, 91, 563-573. [CrossRef]

33. Frank, R.; Ahrens, V.; Boehnke, S.; Hofmann, S.; Kellert, M.; Saretz, S.; Pandey, S.; Sárosi, M.; Bartók, Á.; Beck-Sickinger, A.G.; et al. Carbaboranes-More Than Just Phenyl Mimetics. Pure Appl. Chem. 2015, 87, 163-171. [CrossRef]

34. Wilkinson, S.M.; Gunosewoyo, H.; Barron, M.L.; Boucher, A.; McDonnell, M.; Turner, P.; Morrison, D.E.; Bennett, M.R.; McGregor, I.S.; Rendina, L.M.; et al. The First CNS-Active Carborane: A Novel P2X 7 Receptor Antagonist with Antidepressant Activity. ACS Chem. Neurosci. 2014, 5, 335-339. [CrossRef] [PubMed]

35. Moss, R.L. Critical Review, with an Optimistic Outlook, on Boron Neutron Capture Therapy (BNCT). Appl. Radiat. Isot. 2014, 88, 2-11. [CrossRef] [PubMed]

36. Hawkins, P.M.; Jelliss, P.A.; Nonaka, N.; Shi, X.; Banks, W.A. Permeability of the Blood-Brain Barrier to a Rhenacarborane. J. Pharmacol. Exp. Ther. 2009, 329, 608-614. [CrossRef] [PubMed]

37. Crossley, E.L.; Issa, F.; Scarf, A.M.; Kassiou, M.; Rendina, L.M. Synthesis and Cellular Uptake of Boron-rich Pyrazolopyrimidines: Exploitation of the Translocator Protein for the Efficient Delivery of Boron into Human Glioma Cells. Chem. Commun. 2011, 47, 12179. [CrossRef]

38. Reetz, M.T.; Chatziiosifidis, I.; Künzer, H.; Müller-Starke, H. Trimethylsilyl Cyanide Promoted Cyanation of Tertiary Alkyl Chlorides and other $\mathrm{S}_{\mathrm{N}} 1$ Active Compounds. Tetrahedron 1983, 39, 961-965. [CrossRef]

39. Neumann, W.; Xu, S.; Sárosi, M.B.; Scholz, M.S.; Crews, B.C.; Ghebreselasie, K.; Banerjee, S.; Marnett, L.J.; Hey-Hawkins, E. nido-Dicarbaborate Induces Potent and Selective Inhibition of Cyclooxygenase-2. ChemMedChem 2016, 11, 175-178. [CrossRef]

40. Yung-Chi, C.; Prusoff, W.H. Relationship between the Inhibition Constant $\left(\mathrm{K}_{\mathrm{I}}\right)$ and the Concentration of Inhibitor which Causes 50 per cent Inhibition ( $\mathrm{I}_{50}$ ) of an Enzymatic Reaction. Biochem. Pharmacol. 1973, 22, 3099-3108. [CrossRef]

41. Kalgutkar, A.S.; Marnett, A.B.; Crews, B.C.; Remmel, R.P.; Marnett, L.J. Ester and Amide Derivatives of the Nonsteroidal Antiinflammatory Drug, Indomethacin, as Selective Cyclooxygenase-2 Inhibitors. J. Med. Chem. 2000, 43, 2860-2870. [CrossRef]

42. Smith, T.; Leipprandt, J.; DeWitt, D. Purification and Characterization of the Human Recombinant Histidine-Tagged Prostaglandin Endoperoxide H Synthases-1 and -2. Arch. Biochem. Biophys. 2000, 375, 195-200. [CrossRef] [PubMed] 
43. Hood, W.F.; Gierse, J.K.; Isakson, P.C.; Kiefer, J.R.; Kurumbail, R.G.; Seibert, K.; Monahan, J.B. Characterization of Celecoxib and Valdecoxib Binding to Cyclooxygenase. Mol. Pharmacol. 2003, 63, 870-877. [CrossRef] [PubMed]

44. Laube, M.; Gassner, C.; Neuber, C.; Wodtke, R.; Ullrich, M.; Haase-Kohn, C.; Löser, R.; Köckerling, M.; Kopka, K.; Kniess, T.; et al. Deuteration Versus Ethylation-Strategies to Improve the Metabolic Fate of an ${ }^{18}$ F-Labeled Celecoxib Derivative. RSC Adv. 2020, 10, 38601-38611. [CrossRef]

45. Donovan, S.F.; Pescatore, M.C. Method for Measuring the Logarithm of the Octanol-Water Partition Coefficient by Using Short Octadecyl-poly(vinyl alcohol) High-Performance Liquid Chromatography Columns. J. Chromatogr. A 2002, 952, 47-61. [CrossRef]

46. Wagner, B.; Fischer, H.; Kansy, M.; Seelig, A.; Assmus, F. Carrier Mediated Distribution System (CAMDIS): A New Approach for the Measurement of Octanol/Water Distribution Coefficients. Eur. J. Pharm. Sci. 2015, 68, 68-77. [CrossRef]

47. Denkert, C.; Köbel, M.; Berger, S.; Siegert, A.; Leclere, A.; Trefzer, U.; Hauptmann, S. Expression of Cyclooxygenase 2 in Human Malignant Melanoma. Cancer Res. 2001, 61, 303-308. [PubMed]

48. Xu, X.-T.; Hu, W.-T.; Zhou, J.-Y.; Tu, Y. Celecoxib Enhances the Radiosensitivity of HCT116 Cells in a COX-2 Independent Manner by Up-Regulating BCCIP. Am. J. Transl. Res. 2017, 9, 1088-1100.

49. Roller, A.; Bähr, O.R.; Streffer, J.; Winter, S.; Heneka, M.; Deininger, M.; Meyermann, R.; Naumann, U.; Gulbins, E.; Weller, M. Selective Potentiation of Drug Cytotoxicity by NSAID in Human Glioma Cells: The Role of COX-1 and MRP. Biochem. Biophys. Res. Commun. 1999, 259, 600-605. [CrossRef]

50. Kuipers, G.K.; Slotman, B.J.; Wedekind, L.E.; Stoter, T.R.; van den Berg, J.; Sminia, P.; Lafleur, M.V.M. Radiosensitization of Human Glioma Cells by Cyclooxygenase-2 (COX-2) Inhibition: Independent on COX-2 Expression and Dependent on the COX-2 Inhibitor and Sequence of Administration. Int. J. Radiat. Biol. 2007, 83, 677-685. [CrossRef]

51. Green, J.A.; Stockton, R.A.; Johnson, C.; Jacobson, B.S. 5-Lipoxygenase and Cyclooxygenase Regulate Wound Closure in NIH/3T3 Fibroblast Monolayers. Am. J. Physiol. Physiol. 2004, 287, C373-C383. [CrossRef]

52. Zhou, P.; Qin, J.; Li, Y.; Li, G.; Wang, Y.; Zhang, N.; Chen, P.; Li, C. Combination Therapy of PKCᄃ and COX-2 Inhibitors Synergistically Suppress Melanoma Metastasis. J. Exp. Clin. Cancer Res. 2017, 36, 115. [CrossRef] [PubMed]

53. Oksuz, E.; Atalar, F.; Tanırverdi, G.; Bilir, A.; Shahzadi, A.; Yazici, Z. Therapeutic Potential of Cyclooxygenase-3 Inhibitors in the Management of Glioblastoma. J. Neurooncol. 2016, 126, 271-278. [CrossRef]

54. Page, R.M.; Baumann, K.; Tomioka, M.; Pérez-Revuelta, B.I.; Fukumori, A.; Jacobsen, H.; Flohr, A.; Luebbers, T.; Ozmen, L.; Steiner H.; et al. Generation of A $\beta 38$ and A $\beta 42$ Is Independently and Differentially Affected by Familial Alzheimer Disease-Associated Presenilin Mutations and $\gamma$-Secretase Modulation. J. Biol. Chem. 2008, 283, 677-683. [CrossRef]

55. Kretner, B.; Fukumori, A.; Gutsmiedl, A.; Page, R.M.; Luebbers, T.; Galley, G.; Baumann, K.; Haass, C.; Steiner, H. Attenuated A $\beta 42$ Responses to Low Potency $\gamma$-Secretase Modulators Can Be Overcome for Many Pathogenic Presenilin Mutants by Secondgeneration Compounds. J. Biol. Chem. 2011, 286, 15240-15251. [CrossRef] [PubMed]

56. Crump, C.J.; Johnson, D.S.; Li, Y.-M. Development and Mechanism of $\gamma$-Secretase Modulators for Alzheimer's Disease. Biochemistry 2013, 52, 3197-3216. [CrossRef] [PubMed]

57. Bregadze, V.I. Dicarba-closo-dodecaboranes $\mathrm{C}_{2} \mathrm{~B}_{10} \mathrm{H}_{12}$ and Their Derivatives. Chem. Rev. 1992, 92, 209-223. [CrossRef]

58. Scholz, M.; Steinhagen, M.; Heiker, J.T.; Beck-Sickinger, A.G.; Hey-Hawkins, E. Asborin Inhibits Aldo/Keto Reductase 1A1. ChemMedChem 2011, 6, 89-93. [CrossRef]

59. Schjerning, A.-M.; McGettigan, P.; Gislason, G. Cardiovascular Effects and Safety of (Non-Aspirin) NSAIDs. Nat. Rev. Cardiol. 2020, 17, 574-584. [CrossRef]

60. Suwanjang, W.; Wu, K.L.H.; Prachayasittikul, S.; Chetsawang, B.; Charngkaew, K. Mitochondrial Dynamics Impairment in Dexamethasone-Treated Neuronal Cells. Neurochem. Res. 2019, 44, 1567-1581. [CrossRef]

61. Honjo, H.; Uwai, Y.; Aoki, Y.; Iwamoto, K. Stereoselective Inhibitory Effect of Flurbiprofen, Ibuprofen and Naproxen on Human Organic Anion Transporters hOAT1 and hOAT3. Biopharm. Drug Dispos. 2011, 32, 518-524. [CrossRef]

62. Vellonen, K.-S.; Häkli, M.; Merezhinskaya, N.; Tervo, T.; Honkakoski, P.; Urtti, A. Monocarboxylate Transport in Human Corneal Epithelium and Cell Lines. Eur. J. Pharm. Sci. 2010, 39, 241-247. [CrossRef] [PubMed]

63. Parepally, J.M.R.; Mandula, H.; Smith, Q.R. Brain Uptake of Nonsteroidal Anti-Inflammatory Drugs: Ibuprofen, Flurbiprofen, and Indomethacin. Pharm. Res. 2006, 23, 873-881. [CrossRef] [PubMed]

64. Goszczyński, T.M.; Fink, K.; Kowalski, K.; Leśnikowski, Z.J.; Boratyński, J. Interactions of Boron Clusters and their Derivatives with Serum Albumin. Sci. Rep. 2017, 7, 9800. [CrossRef]

65. Buzharevski, A.; Paskas, S.; Sárosi, M.; Laube, M.; Lönnecke, P.; Neumann, W.; Mijatovic, S.; Maksimovic-Ivanic, D.; Pietzsch, J.; Hey-Hawkins, E. Carboranyl Analogues of Celecoxib with Potent Cytostatic Activity against Human Melanoma and Colon Cancer Cell Lines. ChemMedChem 2019, 14, 315-321. [CrossRef]

66. Buzharevski, A.; Paskaš, S.; Sárosi, M.-B.; Laube, M.; Lönnecke, P.; Neumann, W.; Murganić, B.; Mijatović, S.; Maksimović-Ivanić, D.; Pietzsch, J.; et al. Carboranyl Derivatives of Rofecoxib with Cytostatic Activity against Human Melanoma and Colon Cancer Cells. Sci. Rep. 2020, 10, 4827. [CrossRef] [PubMed]

67. Mijatovic, S.; Maksimovic-Ivanic, D.; Radovic, J.; Popadic, D.; Momcilovic, M.; Harhaji, L.; Miljkovic, D.; Trajkovic, V. Aloe-Emodin Prevents Cytokine-Induced Tumor Cell Death: The Inhibition of Auto-Toxic Nitric Oxide Release as a Potential Mechanism. Cell. Mol. Life Sci. 2004, 61, 1805-1815. [CrossRef]

68. Zakharkin, L.I.; Ol'shevaskaya, V.A. Experimental Estimation of the Distribution of Electron Density on the $o^{-}, m-$, and $p$-Carborane Skeleton by Use of Carboranecarboxylic Acids. Zhurnal Obs. Khimii 1987, 57, 368-372. 
69. Spokoyny, A.M.; Lewis, C.D.; Teverovskiy, G.; Buchwald, S.L. Extremely Electron-Rich, Boron-Functionalized, Icosahedral Carborane-Based Phosphinoboranes. Organometallics 2012, 31, 8478-8481. [CrossRef]

70. Harris, R.K.; Becker, E.D.; Cabral De Menezes, S.M.; Goodfellow, R.; Granger, P. NMR Nomenclature: Nuclear Spin Properties and Conventions for Chemical Shifts (IUPAC Recommendations 2001). Concepts Magn. Reson. 2002, 14, 326-346. [CrossRef]

71. Isotope Distribution Calculator and Mass Spec Plotter. Available online: http://www.sisweb.com/mstools/isotope.htm (accessed on 30 September 2017). 